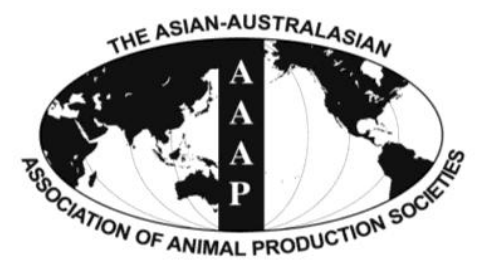

Asian-Aust. J. Anim. Sci.

Vol. 25, No. $10: 1364$ - 1373

October 2012

www.ajas.info

http://dx.doi.org/10.5713/ajas.2012.12051

\title{
Effect of Cassava Hay and Rice Bran Oil Supplementation on Rumen Fermentation, Milk Yield and Milk Composition in Lactating Dairy Cows
}

\author{
R. Lunsin, M. Wanapat* and P. Rowlinson ${ }^{1}$ \\ Tropical Feed Resources Research and Development Center (TROFREC), Faculty of Agriculture, \\ Khon Kaen University, Khon Kaen, 40002, Thailand
}

\begin{abstract}
Four crossbred (75\% Holstein Friesian) lactating dairy cows, with an average live weight of $418 \pm 5 \mathrm{~kg}$ and $36 \pm 10 \mathrm{~d}$ in milk were randomly assigned according to a $2 \times 2$ factorial arrangement in a $4 \times 4$ Latin square design to evaluate the effects of cassava hay $(\mathrm{CH})$ and rice bran oil (RBO) on feed intake, nutrient digestibility, ruminal fermentation, milk yield, and milk composition. Factor A was non-supplementation or supplementation with $\mathrm{CH}$ in the concentrate. Factor B was supplementation with $\mathrm{RBO}$ at $0 \%$ or $4 \%$ in the concentrate mixture. The four dietary treatments were (T1) control (Concentrate with non-CH plus 0\% RBO; C), (T2) Concentrate with $\mathrm{CH}$ plus $0 \% \mathrm{RBO}(\mathrm{CH})$, (T3) Concentrate with non- $\mathrm{CH}$ plus $4 \% \mathrm{RBO}(\mathrm{RBO})$, and (T4) Concentrate with $\mathrm{CH}$ plus $4 \% \mathrm{RBO}(\mathrm{CHRBO})$. The cows were offered concentrate, at a ratio of concentrate to milk production of 1:2, and urea-lime treated rice straw was fed ad libitum. Urea-lime treated rice straw involved $2.5 \mathrm{~g}$ urea and $2.5 \mathrm{~g} \mathrm{Ca}(\mathrm{OH})_{2}$ (purchased as hydrated lime) in $100 \mathrm{ml}$ water, the relevant volume of solution was sprayed onto a $100 \mathrm{~g}$ air-dry $(91 \% \mathrm{DM})$ straw, and then covering the stack with a plastic sheet for a minimum of $10 \mathrm{~d}$ before feeding directly to animals. The $\mathrm{CH}$ based concentrate resulted in significantly higher roughage intake and total DM intake expressed as a percentage of $\mathrm{BW}(\mathrm{p}<0.05)$. Ruminal $\mathrm{pH}, \mathrm{NH}_{3}-\mathrm{N}, \mathrm{BUN}$ and total VFA did not differ among treatments, while $\mathrm{RBO}$ supplementation increased propionate, but decreased acetate concentration $(\mathrm{p}<0.05)$. Furthermore, the population of total ruminal bacteria was significantly lower on the RBO diet $(\mathrm{p}<0.05)$. In contrast, the total ruminal bacteria and cellulolytic bacteria on the $\mathrm{CH}$ diet were higher than on the other treatments. Supplementation with $\mathrm{CH}$ increased $(\mathrm{p}<0.05)$ F. succinogens and $R$. flavefaciens populations, whereas the populations of $B$. fibrisolvens and $M$. elsdenii were increased on the RBO diet. In addition, supplementation with $\mathrm{CH}$ and RBO had no effect on milk production and composition in dairy cows, while fatty acid composition of milk was influenced by RBO supplementation, and resulted in significantly lower $(\mathrm{p}<0.05)$ concentrations of both short-chain and medium-chain FA, and increased $(\mathrm{p}<0.05)$ the proportion of long-chain FA in milk fat, as well as significantly increased cis-9, trans-11 CLA and total CLA. In conclusion, $\mathrm{RBO}$ or $\mathrm{CH}$ exhibited specific effects on DMI, rumen fermentation, microbial population, milk yield and composition in lactating dairy cows, which were not interactions between $\mathrm{CH}$ and RBO in the diets. Feeding lactating dairy cows with RBO could improve fatty acid in milk fat by increasing cis-9, trans-11 CLA. (Key Words: Cassava Hay, Rice Bran Oil, Rumen Fermentation, Milk Yield and Composition, Lactating Dairy Cows)
\end{abstract}

\section{INTRODUCTION}

Meeting the energy and protein requirements of cows in early lactation, especially, high producing cows, is particularly challenging in the tropics. Due to energy and protein are the most significant factors affecting dairy cow performance (NRC, 2001). In early lactation, most cows

\footnotetext{
* Corresponding Author: Metha Wanapat. Tel: +66-43-202368, Fax: +66-43-202368, E-mail: metha@kku.ac.th

${ }^{1}$ School of Agriculture, Food and Rural Development, Newcastle University, Newcastle Upon Tyne, NE1 7RU, United Kingdom. Submitted Jan. 31, 2012; Accepted Apr. 15, 2012; Revised Jun. 5, 2012
}

will actually lose a considerable amount of weight and milk production, because nutrient intake is less than needed to meet the nutrient demands of milk production. As a result, supplementation with protein sources and fat or oil-rich feedstuffs is a logical step to increase the protein and energy content of rations to meet the requirements of lactating cows (Chantaprasarn and Wanapat, 2008).

Cassava hay is one of the alternative protein sources for ruminants. Cassava hay contains about $25 \%$ crude protein with a relatively good profile of amino acids with higher levels of leucine, isoleucine, glutamine, esparagine, methionine, lysine and alanine as compared to soybean 
meal and alfalfa hay (Wanapat et al., 2000b; Wanapat, 2002). Feeding cassava hay as a supplemental protein source can increase milk yield and improve milk composition, and could significantly reduce concentrate use in lactating dairy cows (Wanapat et al., 2001). Wanapat et al. (2000a) showed that increasing the level of cassava hay from 0.56 to $1.70 \mathrm{~kg} / \mathrm{head} / \mathrm{d}$ in late-lactating dairy cows could reduce levels of concentrate from 0.1 to $1.6 \mathrm{~kg} / \mathrm{head} / \mathrm{d}$ without affecting milk yield. Furthermore, cassava hay supplementation could also significantly enhance $3.5 \%$ fat corrected milk (FCM), milk fat and milk protein. Similarly, Wanapat et al. (2000b) found that supplementation of cassava hay to replace concentrate in mid-lactating dairy cows did not affect milk yields, while protein, lactose and solids-not fat were highest in cows fed with cassava hay at $1.0 \mathrm{~kg} / \mathrm{head} / \mathrm{d}$. In addition, the most significant improvement from cassava hay supplementation was the ability to reduce concentrate use by $42 \%$ (compared with control) which provided a greater economic return (Wanapat et al., 2000b).

Lipid supplementation has been used for years in dairy nutrition to increase energy density in the diet (Jenkins and McGuire, 2006). Moreover, manipulating the diet of dairy cows by added lipid is one way to alter the fatty acid in milk fat to enhance the proportions of desirable unsaturated fatty acids in edible products (Raes et al., 2004; Bu et al., 2007). Dairy products enriched with polyunsaturated fatty acids (PUFA) or conjugated linoleic acid (CLA) could offer potential benefits in human health (Bouattour et al., 2008). Recently, there has been interest in enhancing the concentration of CLA in bovine milk due to its potential as a protective agent against cancer and cardiovascular disease (Roche et al., 2001). The primary isomers of CLA that have been associated with health benefits are cis-9, tran-11 CLA (Bu et al., 2007). Vegetable oils are one lipid source that has been used in dairy cow diets to increases energy intake to support higher milk yield during early lactation. Furthermore, supplementing vegetable oils such as soybean, sunflower, linseed, corn, or rice bran oil, has been confirmed as an effective nutritional strategy to increase cis-9, tran-11 CLA in lactating dairy cows. Recent studies by Lunsin et al. (2012) found that feeding lactating dairy cows with rice bran oil could increase cis-9, tran-11 CLA in milk, while not affecting milk yield. Similarly, Chantaraparn and Wanapat (2008) showed that supplementation of cassava hay based diets with sunflower oil improves rumen fermentation, milk yield and milk fatty acid content, especially in terms of conjugated linoleic acids (CLA). However, there have not been any studies on cassava hay based-concentrate with rice bran oil in lactating dairy cows. Therefore, the objective of this study was to investigate the effect of supplementation with cassava hay and rice bran oil on rumen fermentation, microorganisms, milk yield, milk composition and fatty acids profile in lactating dairy cows fed on urea-lime treated rice straw.

\section{MATERIALS AND METHODS}

\section{Animals, diets and experimental design}

Four, multiparous early-lactation crossbred dairy cows (75\% Holstein Friesian) with an average $418 \pm 5 \mathrm{~kg} \mathrm{BW}$ and $36 \pm 10$ DIM, were randomly assigned according to $2 \times 2$ factorial arrangement in a $4 \times 4$ Latin square design. Factor A was non-supplementation or supplementation with cassava hay $(\mathrm{CH})$ in the concentrate. Factor $\mathrm{B}$ was rice bran oil (RBO) at $0 \%$ or $4 \%$ in the concentrate mixture. The treatments were as follows; (T1) control (C), (T2) concentrate with $\mathrm{CH}(\mathrm{CH}),(\mathrm{T} 3)$ concentrate with $4 \%$ RBO (RBO) and (T4) concentrate with $\mathrm{CH}$ plus $4 \% \mathrm{RBO}$ (CHRBO). Cows received the concentrate diet at a ratio of milk yield to concentrate of 2:1 and urea-lime treated rice straw (ULRS) was offered ad libitum as a roughage source. Urea-lime treated rice straw involved $2.5 \mathrm{~g}$ urea and $2.5 \mathrm{~g}$ $\mathrm{Ca}(\mathrm{OH})_{2}$ (purchased as hydrated lime) in $100 \mathrm{ml}$ water, the relevant volume of solution was sprayed onto a $100 \mathrm{~g}$ airdry $(91 \% \mathrm{DM})$ straw, and then covering the stack with a plastic sheet for a minimum of $10 \mathrm{~d}$ before feeding directly to animals. All cows were housed in individual pens $(3 \times 5$ $\mathrm{m} /$ head, with concrete flooring), and received free access to water and a mineral-salt block. The experiment was run in four periods, each experimental period lasted for $21 \mathrm{~d}$. The first $14 \mathrm{~d}$ of each period were for treatment adaptation and for feed intake measurements, whilst during the last $7 \mathrm{~d}$ feed, feces, refusals and milk were sampled for subsequent chemical analyses. Chemical composition and components of the experimental diets are shown in Table 1.

\section{Data collection and sampling procedures}

Feed intakes were measured and refusals recorded daily during the $21 \mathrm{~d}$ of each period. Body weights were measured daily during the sampling period prior to feeding. Feeds were sampled daily during the collection period and were composited by period prior to analyses. Feed and fecal samples were collected during the last $5 \mathrm{~d}$ of each period. Fecal samples were collected twice daily by rectal grab sampling (morning and afternoon) after milking. Composited samples were dried at $60^{\circ} \mathrm{C}$ and ground $(1 \mathrm{~mm}$ screen using Cyclotech Mill, Tecator, Sweden) and then analysed for DM, EE, ash and CP content (AOAC, 1990), NDF and ADF (Goering and Van Soest, 1970) and acidinsoluble ash (AIA). AIA was used to estimate digestibility of nutrients (Van Keulen and Young, 1977).

Cows were milked twice daily at 05.30 am and 15.30 pm into buckets and milk yield was recorded at each milking of each period. Milk samples were composed daily, according to yield, for $50 \%$ of both the morning and 
Table 1. Feed ingredients and chemical composition used in the experimental diets

\begin{tabular}{lcrrrr}
\hline Item & Control & CH & RBO & CHRBO & ULRS $^{1}$ \\
\hline Ingredients (\%) & & & & & \\
Cassava hay (CH) & - & 13.0 & - & 13.0 & \\
Rice bran oil (RBO) & - & - & 4.0 & 4.0 & \\
Cassava chip & 62.0 & 62.0 & 62.0 & 62.0 & \\
Soybean meal & 6.0 & 3.5 & 6.0 & 4.0 & \\
Fine rice bran & 7.5 & 4.0 & 6.0 & 3.0 & \\
Coconut meal & 7.0 & 4.0 & 6.5 & 3.5 & \\
Brewerys' grain & 8.0 & 4.0 & 8.0 & 3.0 & \\
Urea & 3.0 & 3.0 & 3.0 & 3.0 & \\
Molasses & 4.0 & 4.0 & 2.0 & 2.0 & \\
Sulfur & 0.5 & 0.5 & 0.5 & 0.5 & \\
Mineral mixture & 0.5 & 0.5 & 0.5 & 0.5 & \\
Salt & 0.5 & 0.5 & 0.5 & 0.5 & \\
Chemical compositions $(\%$ of DM) & & & \\
DM & 87.5 & 87.6 & 89.4 & 89.6 & 63.3 \\
& -------------- & \\
OM & 90.6 & 91.3 & 91.8 & 91.6 & 84.7 \\
Ash & 9.4 & 8.7 & 8.2 & 8.4 & 15.3 \\
CP & 18.1 & 18.0 & 18.0 & 17.9 & 5.0 \\
EE & 4.0 & 3.9 & 7.1 & 6.9 & 1.8 \\
NDF & 21.4 & 24.3 & 20.8 & 22.0 & 70.9 \\
ADF & 15.5 & 16.4 & 14.9 & 15.1 & 47.2 \\
TDN & 77.4 & 76.8 & 79.4 & 78.6 & - \\
\hline
\end{tabular}

${ }^{1}$ ULRS = Urea-lime treated rice straw; DM = Dry matter; OM = Organic matter; $\mathrm{CP}=$ Crude protein, $\mathrm{NDF}=$ Neutral detergent fiber; $\mathrm{ADF}=$ Acid detergent fiber; TDN $=$ Total digestible of nutreint (calculated values).

afternoon milking, then pooled by equal volume on the last $5 \mathrm{~d}(50 \mathrm{ml} / \mathrm{d})$ of each period. Two $50-\mathrm{ml}$ of milk sample were analyzed for milk composition. First part of each milk sample was preserved with 2-bromo-2 nitropropane-1, 3dial, and stored at $4{ }^{\circ} \mathrm{C}$ until analysis for fat, protein, lactose, total solids and solid-not-fat content (AOAC, 1990) by infrared methods using Milko-Scan 33 (Foss Electric, Hillerod, Demark). Milk urea N (MUN) was determined using Sigma kits \#640 (Sigma Diagnostics, St. Louis, MO, USA) (Valladares et al., 1999). The other part of each milk sample was dried by a freeze dry method (Heto Power Dry LL3000 Freeze Dryer; Thermo Fisher Scientific, TehovecMukarov, Czech Republic) and analyzed for fatty acid content. For the fatty acid analysis, $50 \mathrm{ml}$ of each sample was added to a flask and $2 \mathrm{ml}$ of ethanol was added to moisturize the sample. Subsequently, $10 \mathrm{ml}$ of $\mathrm{HCl}(8$ $\mathrm{mol} / \mathrm{L}$ ) was added; the contents were gently mixed, and the flask was placed in a water bath at $80^{\circ} \mathrm{C}$ for 30 to $40 \mathrm{~min}$. The tubes were cooled down, $10 \mathrm{ml}$ of ethanol (96\%) and $25 \mathrm{ml}$ of petroleum ether (boiling point between 40 and $60^{\circ} \mathrm{C}$ ) were added and the tube was vigorously shaken for 1 $\mathrm{min}$. The fat-containing upper layer was decanted into a 150 $\mathrm{ml}$ round-bottom flask. The extraction procedure was repeated twice with $15 \mathrm{ml}$ of diethyl ether and $15 \mathrm{ml}$ of petroleum ether and the lipid extract was evaporated to dryness under $\mathrm{N}$ in a water bath at $40^{\circ} \mathrm{C}$. The lipidcontaining round-bottom flasks were dried overnight at $60^{\circ} \mathrm{C}$ and the total lipids were measured gravimetrically. Total lipids were saponified and methylated according to the procedure of Metcalfe et al. (1966) followed by gas liquid chromatography (Nelson, 1975) using a flame ionization detector, a Chrompack column (Fused silica, no.7485, CP.FFAPCB $25 \mathrm{~m} \times 0.32 \mathrm{~mm}$, Chrompack, Middelburg, The Netherlands) and $\mathrm{H}$ as carrier gas. The individual fatty acids were expressed as weight percentage of total methyl esters.

Rumen fluid samples were collected at 0 and $4 \mathrm{~h}$-post feeding at the end of each period. Approximately $200 \mathrm{ml}$ of rumen fluid was taken from the middle part of the rumen by a stomach tube connected with a vacuum pump. Rumen fluid was immediately measured for $\mathrm{pH}$ and temperature using a portable $\mathrm{pH}$ and temperature meter (HANNA instrument HI 8424 microcomputer, Singapore). Rumen fluid samples were then filtered through four layers of cheesecloth. Samples were divided into three portions. One portion was used for $\mathrm{NH}_{3}-\mathrm{N}$ analyses where $5 \mathrm{ml}$ of $\mathrm{H}_{2} \mathrm{SO}_{4}$ solution $(1 \mathrm{M})$ was added to $50 \mathrm{ml}$ of rumen fluid. The mixture was centrifuged at $16,000 \times g$ for 15 minute and the supernatant stored at $-20^{\circ} \mathrm{C}$ prior to $\mathrm{NH}_{3}-\mathrm{N}$ analysis using the micro Kjeldahl method (AOAC, 1990) and VFA analyses using a HPLC (Samuel et al., 1997). A second portion was taken to study culture groups of viable bacteria using the roll-tube technique described by Hungate (1969), for identifying bacteria groups (cellulolytic, proteolytic, amylolytic and total viable count bacteria) and a third portion was taken to study microorganism populations by using Real-time qPCR technique. Community DNA was extracted from $1.0 \mathrm{ml}$ rumen fluid sample by the $\mathrm{RBB}+\mathrm{C}$ (Yu and Morrison, 2004). Real-time PCR amplication and detection was performed using the Choromo4TM detection system (Bio- Rad, Hercules, CA, USA).

Samples of jugular blood (about $10 \mathrm{ml}$ ) were drawn into serum separation tubes containing $12 \mathrm{mg}$ of EDTA at the same time as rumen fluid sampling and plasma was separated by centrifugation at $5,000 \times g$ for $10 \mathrm{~min}$. The supernatant was decanted and frozen $\left(-20^{\circ} \mathrm{C}\right)$ until it was analyzed for blood urea nitrogen (BUN) according to the method of Crocker (1967).

\section{Statistical analysis}

All data were statistically analyzed as a $2 \times 2$ factorial arrangement in a $4 \times 4$ Latin square design using the General Linear Model (GLM) procedures (SAS, 1996) according to the following model :

$$
\mathrm{Yijk}=\mu+\mathrm{T}_{\mathrm{i}}+\mathrm{P}_{\mathrm{j}}+\mathrm{C}_{\mathrm{k}}+\mathrm{D}_{\mathrm{l}}+\mathrm{AB}_{\mathrm{kl}}+\varepsilon \mathrm{ijkl}
$$


where Yijk $=$ represents of observation from animals, $\mu$ $=$ overall mean, $T_{i}=$ treatment effect $(\mathrm{i}=1$ to 4$), \mathrm{P}_{\mathrm{j}}=$ period effect ( $\mathrm{i}=1$ to 4$), \mathrm{C}_{\mathrm{k}}=$ effect of factor $\mathrm{A}(\mathrm{A}=$ level of $\mathrm{CH}$ in concentrate, $i=1$ to 2$), D_{1}=$ effect of factor $B(B=$ level of $\mathrm{RBO}$ in concentrate, $\mathrm{j}=1$ to 2$), \mathrm{AB}_{\mathrm{kl}}=$ effect of interaction and $\varepsilon i j k=$ random residual. Significant differences between treatments were determined using Duncan's New Multiple Range Test (DMRT) (Steel and Torrie, 1980). Mean separation with a significant $F(\mathrm{p}<0.05)$ for treatment were statistically compared using the orthogonal contrasts.

\section{RESULTS AND DISCUSSIONS}

Feed intakes, nutrient digestibility and nutrient intake

Urea-lime treated rice straw (ULRS) DM intake and total DM intake were significantly higher in animals fed with $\mathrm{CH}$ when expressed as \% BW $(\mathrm{p}<0.05)$. There were not significant differences in DM intake in animals fed with $4 \%$ RBO in the concentrate (Table 2) which agreed with the work of Chantaraparn and Wanapat (2008) who found that total DMI was not significantly different when dairy cows were supplemented with $2.5 \%$ or $5 \%$ sunflower oil. Others have reported no negative influence on feed intake when supplementing soybean oil, in free form, at $3.6 \%$ or linseed oil at $4.4 \%$ (Dhiman et al., 2000) or $2 \%$ rapeseed oil, peanut oil, or sunflower oil (Dai et al., 2011). In this study, DMI was not affected by RBO supplementation, due to the low level of RBO (4\% RBO) in the diet. NRC (2001) recommended that total dietary lipid in ruminant diets should not exceed 6 to $7 \%$ of dietary DM, feeding a higher concentration of oils than this level could result in reduced rumen microbial activities, reduced digestibility and might result in a reduction of dry matter intake (DMI) (Shingfield et al., 2006). Lunsin et al. (2012) reported that supplementation with $\mathrm{RBO}$ at $4 \%$ in concentrate is recommended to obtain the most beneficial effect on DMI in lactating dairy cows. Increased supplemental $\mathrm{RBO}(0,2$,
4 and $6 \%$ ) in dairy cow diets linearly decreased their DMI to the lowest level at $6 \% \mathrm{RBO}$ as compared with other treatments; however, DMI was maintained at $4 \% \mathrm{RBO}$ supplementation as compared with control (0\% RBO).

Supplementation with $4 \%$ RBO resulted in decreased digestion coefficients of OM and DM ( $\mathrm{p}<0.05)$. This result is consistent with Hess et al. (2001) who reported that total tract digestibility of $\mathrm{OM}$ decreased linearly as dietary soybean oil increased (2.9 to 6.2\%). The reason for reducing digestibility when oil is supplemented at a high level is that oil may coat feed particles, which prevents microbial attachment and attack (Devendra and Lewis, 1973). Although supplementing with 4\% RBO decreased $\mathrm{OM}$ digestibility, digestible $\mathrm{OM}$ intakes were not significantly different among treatments. However, cows fed with $\mathrm{CH}$ had a significantly higher apparent digestibility of NDF $(p<0.05)$, as well as tending to be higher in digestible NDF intake ( $p=0.07)$ when compared with non$\mathrm{CH}$ diets. According to Chantaraparn and Wanapat (2008) cows receiving a $\mathrm{CH}$ based-diet tended to be higher in nutrient digestion than the control group. Digestion coefficients of $\mathrm{CP}$ and $\mathrm{ADF}$ and digestible nutrient intakes were similar among treatments. In addition, metabolisable energy (ME) intake per $\mathrm{kg} \mathrm{DM}$ was significantly lower in cows fed with $4 \%$ RBO ( $<<0.05$, Table 3 ). This could be due to OM digestibility was lower in cow fed with RBO.

\section{Rumen fermentation characteristics and blood urea nitrogen}

The effects of $\mathrm{CH}$ and $\mathrm{RBO}$ supplementation on rumen ecology and blood-urea nitrogen (BUN) are presented in Table 4. Supplementation with $\mathrm{CH}$ and $4 \% \mathrm{RBO}$ to dairy cows diets did not affect ruminal $\mathrm{pH}, \mathrm{NH}_{3}-\mathrm{N}$ and $\mathrm{BUN}$, while total VFA was significantly higher in cows fed with $\mathrm{CH}(\mathrm{p}<0.05)$. The $\mathrm{NH}_{3}-\mathrm{N}$ was related to the optimum concentration (8.5 to $30.0 \mathrm{mg} / \mathrm{dl}$ ) in ruminal fluid for microbial growth reported by McDonald et al. (1996) and

Table 2. Effect of cassava hay and rice bran oil on feed intake in lactating dairy cows

\begin{tabular}{|c|c|c|c|c|c|c|c|c|}
\hline \multirow{2}{*}{ Items } & \multirow{2}{*}{ Control $^{1}$} & \multirow{2}{*}{$\mathrm{CH}$} & \multirow{2}{*}{$\mathrm{RBO}$} & \multirow{2}{*}{ CHRBO } & \multirow{2}{*}{ SEM } & \multicolumn{3}{|c|}{ Contrast } \\
\hline & & & & & & $\mathrm{RBO}$ & $\mathrm{CH}$ & Int. \\
\hline \multicolumn{9}{|c|}{ ULRS DM intake } \\
\hline $\mathrm{kg} / \mathrm{d}$ & 7.5 & 7.6 & 7.1 & 7.9 & 0.29 & NS & NS & NS \\
\hline$\% \mathrm{BW}$ & $1.7^{\mathrm{ab}}$ & $1.8^{\mathrm{ab}}$ & $1.7^{\mathrm{b}}$ & $1.9^{\mathrm{a}}$ & 0.06 & NS & $*$ & NS \\
\hline \multicolumn{9}{|c|}{ Concentrate DM intake } \\
\hline $\mathrm{kg} / \mathrm{d}$ & 4.8 & 4.7 & 4.8 & 4.5 & 0.21 & NS & NS & NS \\
\hline$\% \mathrm{BW}$ & 1.2 & 1.2 & 1.1 & 1.1 & 0.05 & NS & NS & NS \\
\hline \multicolumn{9}{|c|}{ Total DM intake } \\
\hline $\mathrm{kg} / \mathrm{d}$ & 12.4 & 12.3 & 11.9 & 12.5 & 0.27 & NS & NS & NS \\
\hline$\% \mathrm{BW}$ & $2.9^{\mathrm{ab}}$ & $3.0^{\mathrm{a}}$ & $2.8^{\mathrm{b}}$ & $3.0^{\mathrm{a}}$ & 0.04 & NS & $*$ & NS \\
\hline
\end{tabular}

${ }^{1}$ Control = Non-supplementation with $\mathrm{CH}$ and $\mathrm{RBO} ; \mathrm{CH}=$ Concentrate with $\mathrm{CH} ; \mathrm{RBO}=$ Concentrate with $4 \% \mathrm{RBO}$; $\mathrm{CHRBO}=\mathrm{Concentrate}$ with $\mathrm{CH}$ plus $4 \%$ RBO. Int. = Interaction. NS = Non-significant difference $(p>0.05)$.

$* \mathrm{p}<0.05$. $^{\mathrm{a}, \mathrm{b}}$ Values on the same row with different superscripts differ $(\mathrm{p}<0.05)$. SEM $=$ Standard error of the mean. 
Table 3. Effect of cassava hay and rice bran oil on nutrient digestibility and nutrient intake in lactating dairy cows

\begin{tabular}{|c|c|c|c|c|c|c|c|c|}
\hline \multirow{2}{*}{ Items } & \multirow{2}{*}{ Control $^{1}$} & \multirow{2}{*}{$\mathrm{CH}$} & \multirow{2}{*}{ RBO } & \multirow{2}{*}{ CHRBO } & \multirow{2}{*}{ SEM } & \multicolumn{3}{|c|}{ Contrast } \\
\hline & & & & & & RBO & $\mathrm{CH}$ & Int. \\
\hline \multicolumn{9}{|c|}{ Apparent digestibility (\%) } \\
\hline $\mathrm{DM}$ & $67.9^{\mathrm{ab}}$ & $69.4^{\mathrm{a}}$ & $62.0^{\mathrm{c}}$ & $64.1^{\mathrm{bc}}$ & 1.39 & $*$ & NS & NS \\
\hline $\mathrm{OM}$ & $71.1^{\mathrm{a}}$ & $72.1^{\mathrm{a}}$ & $67.0^{\mathrm{b}}$ & $69.1^{\mathrm{ab}}$ & 1.11 & $*$ & NS & NS \\
\hline $\mathrm{CP}$ & 63.8 & 67.8 & 62.2 & 62.9 & 2.03 & NS & NS & NS \\
\hline $\mathrm{NDF}$ & $59.6^{\mathrm{ab}}$ & $63.8^{\mathrm{a}}$ & $53.6^{\mathrm{b}}$ & $61.4^{\mathrm{a}}$ & 1.89 & NS & $*$ & NS \\
\hline $\mathrm{ADF}$ & 45.9 & 49.7 & 45.1 & 47.7 & 2.20 & NS & NS & NS \\
\hline \multicolumn{9}{|c|}{ Estimated digestible nutrient intake $(\mathrm{kg} / \mathrm{d})$} \\
\hline $\mathrm{OM}$ & 10.6 & 10.7 & 10.4 & 10.5 & 0.23 & NS & NS & NS \\
\hline $\mathrm{CP}$ & 1.7 & 1.7 & 1.6 & 1.6 & 0.03 & NS & NS & NS \\
\hline $\mathrm{NDF}$ & 4.9 & 5.2 & 4.8 & 4.9 & 0.17 & NS & 0.07 & NS \\
\hline $\mathrm{ADF}$ & 3.4 & 3.5 & 3.3 & 3.3 & 0.12 & NS & NS & NS \\
\hline \multicolumn{9}{|c|}{ Estimated energy intake ${ }^{1}$} \\
\hline $\operatorname{ME}(\mathrm{Mcal} / \mathrm{d})$ & 28.7 & $29 . .3$ & 26.4 & 27.6 & 0.97 & 0.07 & NS & NS \\
\hline $\operatorname{ME}(\mathrm{Mcal} / \mathrm{kg} \mathrm{DM})$ & $2.3^{\mathrm{ab}}$ & $2.4^{\mathrm{a}}$ & $2.2^{\mathrm{b}}$ & $2.3^{\mathrm{ab}}$ & 0.03 & $*$ & NS & NS \\
\hline
\end{tabular}

${ }^{1}$ Control $=$ Non-supplementation with $\mathrm{CH}$ and $\mathrm{RBO} ; \mathrm{CH}=$ Concentrate with $\mathrm{CH}$; $\mathrm{RBO}=\mathrm{Concentrate}$ with $4 \% \mathrm{RBO}$, $\mathrm{CHRBO}=$ concentrate with $\mathrm{CH}$ plus $4 \%$ RBO; Int. = Interaction.

${ }^{1} 1 \mathrm{~kg}$ of digestible organic matter $(\mathrm{DOM})=3.8 \mathrm{Mcal} \mathrm{ME}($ Kearl, 1982). NS = Non-significant difference $(\mathrm{p}>0.05)$.

$* \mathrm{p}<0.05{ }^{\mathrm{a}, \mathrm{b}}$ Values on the same row with different superscripts differ $(\mathrm{p}<0.05)$. SEM = Standard error of the mean.

Wanapat and Pimpa (1999). Also, BUN in this study ranged from 13.1 to $14.7 \mathrm{mg} / \mathrm{dl}$, these values are similar to Roseler et al. (1993) who reported that balanced diets with energy and protein balanced for lactating dairy cows were associated with an average BUN concentration of $15 \mathrm{mg} / \mathrm{dl}$. In general, lipid supplementation has no impact on rumen pH and total VFA (Pantoja et al., 1994). However, when feeding supplemental lipid the molar proportion of ruminal acetate decreased and propionate increased; concomitantly, the acetate:propionate ratio decreased (Onetti et al., 2001). In this study, RBO supplementation increased propionate molar concentration, but decreased acetate concentration which resulted in a decreased $\mathrm{C} 2 / \mathrm{C} 3$ ratio (Table 4).
Similarly, Whitney et al. (1999) reported that molar proportions of ruminal acetate decreased with oil supplementation, while the concentration of ruminal VFA, including propionate, tended to increase with $2.9 \%$ dietary soybean oil. Doreau and Chilliard (1997) noted that a decrease in acetate:propionate ratio in the rumen of animals fed supplemental lipid was accompanied by reduced digestion of OM, primarily the fibrous fraction. Similarly, in this study OM digestibility was lowest in cows fed with $\mathrm{RBO}$, resulting in the lowest VFA concentration. Furthermore, $\mathrm{CH}_{4}$ was significantly decreased as a result of RBO supplementation. The change of $\mathrm{CH}_{4}$ concentration in the rumen is consistent with the reduced acetate:propionate

Table 4. Effect of cassava hay and rice bran oil on rumen fermentation characteristics and blood urea nitrogen in lactating dairy cows

\begin{tabular}{|c|c|c|c|c|c|c|c|c|}
\hline \multirow{2}{*}{ Items } & \multirow{2}{*}{ Control $^{1}$} & \multirow{2}{*}{$\mathrm{CH}$} & \multirow{2}{*}{$\mathrm{RBO}$} & \multirow{2}{*}{ CHRBO } & \multirow{2}{*}{ SEM } & \multicolumn{3}{|c|}{ Contrast } \\
\hline & & & & & & $\mathrm{RBO}$ & $\mathrm{CH}$ & Int. \\
\hline Ruminal pH & 6.9 & 6.8 & 6.9 & 6.8 & 0.05 & NS & NS & $\mathrm{NS}$ \\
\hline $\mathrm{NH}_{3}-\mathrm{N}(\mathrm{mg} / \mathrm{dl})$ & 12.1 & 13.0 & 12.7 & 11.6 & 0.49 & NS & NS & $\mathrm{NS}$ \\
\hline BUN (mg/dl) & 13.4 & 14.7 & 14.2 & 13.1 & 1.26 & NS & NS & NS \\
\hline Total VFA (Mm) & $102.2^{b}$ & $115.9^{\mathrm{a}}$ & $102.1^{\mathrm{b}}$ & $107.7^{\mathrm{b}}$ & 2.29 & NS & $*$ & $\mathrm{NS}$ \\
\hline \multicolumn{9}{|l|}{ VFA (mol/100 mol) } \\
\hline Acetate & $73.8^{\mathrm{a}}$ & $72.31^{\mathrm{ab}}$ & $67.5^{\mathrm{b}}$ & $70.5^{\mathrm{ab}}$ & 1.55 & $*$ & NS & NS \\
\hline Propionate & $16.8^{\mathrm{b}}$ & $18.3^{\mathrm{ab}}$ & $23.2^{\mathrm{a}}$ & $20.1^{\mathrm{ab}}$ & 1.56 & $*$ & NS & NS \\
\hline Butyrate & 9.4 & 9.4 & 9.2 & 9.4 & 0.24 & NS & NS & $\mathrm{NS}$ \\
\hline $\mathrm{C} 2: \mathrm{C} 3$ & 4.4 & 4.0 & 3.9 & 3.0 & 0.38 & 0.08 & NS & NS \\
\hline $\mathrm{CH}_{4}^{2}(\mathrm{~mol} / 100 \mathrm{~mol})$ & $32.3^{\mathrm{a}}$ & $31.2^{\mathrm{a}}$ & $27.8^{\mathrm{b}}$ & $29.9^{\mathrm{ab}}$ & 1.13 & $*$ & NS & NS \\
\hline
\end{tabular}

${ }^{1}$ Control $=$ Non-supplementation with $\mathrm{CH}$ and $\mathrm{RBO} ; \mathrm{CH}=$ Concentrate with $\mathrm{CH}$; $\mathrm{RBO}=\mathrm{Concentrate}$ with $4 \% \mathrm{RBO}$; $\mathrm{CHRBO}=\mathrm{Concentrate}$ with $\mathrm{CH}$ plus $4 \%$ RBO; Int. = Interaction. NS = Non-significant difference $(\mathrm{p}>0.05)$.

$* \mathrm{p}<0.05$. ${ }^{\mathrm{a}, \mathrm{b}}$ Values on the same row with different superscripts differ $(\mathrm{p}<0.05)$. SEM $=$ Standard error of the mean.

${ }^{2}$ Estimated: $\mathrm{CH}_{4}=(0.45 \times$ acetate $)-(0.275 \times$ propionate $)+(0.40 \times$ butyrate $)($ Moss et al., 2000$)$. 
when feeding lipid. In addition, supplemental medium chain and/or unsaturated fatty acids can reduce methane emission from ruminants (McGinn et al., 2004; Beauchemin et al., 2008) due to a shift of metabolic $\mathrm{H}_{2}$ from the production of $\mathrm{CH}_{4}$ to the biohydrogenation of the unsaturated FA which could also have contributed to the reduction in enteric $\mathrm{CH}_{4}$ (Clapperton, 1974).

\section{Rumen microorganisms population}

Data on ruminal microorganisms by using a roll-tube technique are summarized in Table 5. Total viable bacterial were affected by $\mathrm{CH}$ and $4 \%$ RBO. Supplementation with $\mathrm{CH}$ significantly increased total viable bacteria $(\mathrm{p}<0.05)$ and as well tending to increase cellulolytic bacterial population $(\mathrm{p}=0.08)$, while total viable bacteria were significantly decreased as a result of RBO supplementation $(\mathrm{p}<0.05)$. This result was consistent with the previous study by Mapato et al. (2010) who found that total viable and cellulolytic bacteria in rumen fluid was significantly decreased with increasing sunflower oil (3 to 6\%) in dairy cows. Similarly, Yang et al. (2009) reported that marked decreases in cellulolytic bacteria numbers were observed when supplemental oils were fed. These effects were possibly associated with direct inhibition and/or the coating action of the unsaturated fatty acids on microorganisms. Also, supplementation with $\mathrm{CH}$ and $\mathrm{RBO}$ did not affect the proteolytic and amylolytic bacteria population, as determined by the direct count technique.

Real-time PCR quantification of ruminal microorganism populations were influenced by dietary treatments (Table 5). It was found that the total bacterial population, $R$. flavefaciens and F. succinogens were all significantly increased on the $\mathrm{CH}$ diets $(\mathrm{p}<0.05)$. This could be due to the cows fed with $\mathrm{CH}$ having a significantly higher fiber digestibility. However, B. fibrisolvens and M. elsdenii populations in RBO diets were significantly higher than in other treatments $(\mathrm{p}<0.05)$, while total bacterial populations and $R$. flavefaciens were significantly lower $(\mathrm{p}<0.05)$. Yang et al. (2009) found that cows fed soybean oil or linseed oil or soybean oil plus linseed oil had a lower DNA quantity of ruminal bacteria associated with biohydrogenation ( $B$. fibrisolvens and $R$. albus) and also fibrolytic bacteria $(F$. succinogenes and $R$. flavefaciens). Kepler et al. (1966) reported that PUFA were particularly toxic, and other longchain fatty acids were also toxic to some of the cellulolytic bacteria found in the rumen (Maczulak et al., 1981). In addition, anaerobic fungi, methanogens and $R$. albus were not significantly different among treatments $(\mathrm{p}>0.05)$. Liu et al. (2010) found that $R$. flavefaciens and $R$. albus DNA copy numbers were similar in beef steers fed with oil and control diet. This implies that these bacteria were not sensitive to dietary oil supplementation.

\section{Milk production and composition}

The influence of $\mathrm{CH}$ and $\mathrm{RBO}$ on yields and composition of milk are shown in Table 6. In this study, milk yield and composition was not significantly different with RBO supplementation to the diets. This result is consistent with Dhiman et al. (2000) who reported that milk yield was similar in all dairy cattle supplemented with 1, 2, 3 or $4 \%$ soybean oil in the diets. Cant et al. (1997) suggested that milk yield would have been affected by oil when the rate of addition was $500 \mathrm{~g} / \mathrm{d}$ upwards. Cows receiving less than $500 \mathrm{~g} / \mathrm{d}$ of oil showed no effects on milk

Table 5. Effect of cassava hay and rice bran oil on rumen microorganism population in lactating dairy cows

\begin{tabular}{|c|c|c|c|c|c|c|c|c|}
\hline \multirow{2}{*}{ Items } & \multirow{2}{*}{ Control $^{1}$} & \multirow{2}{*}{$\mathrm{CH}$} & \multirow{2}{*}{$\mathrm{RBO}$} & \multirow{2}{*}{ CHRBO } & \multirow{2}{*}{ SEM } & \multicolumn{3}{|c|}{ Contrast } \\
\hline & & & & & & $\mathrm{RBO}$ & $\mathrm{CH}$ & Int. \\
\hline \multicolumn{9}{|l|}{ Total viable count $(\mathrm{CFU} / \mathrm{ml})$} \\
\hline Total bacteria $\left(\times 10^{7}\right)$ & $2.59^{\mathrm{a}}$ & $3.13^{\mathrm{a}}$ & $1.71^{\mathrm{b}}$ & $2.71^{\mathrm{a}}$ & 2.52 & $*$ & $*$ & NS \\
\hline Cellulolytic $\left(\times 10^{7}\right)$ & 1.36 & 2.60 & 1.26 & 2.13 & 5.00 & NS & 0.08 & NS \\
\hline Proteolytic $\left(\times 10^{6}\right)$ & 4.40 & 6.32 & 4.22 & 5.52 & 0.96 & NS & NS & NS \\
\hline Amylolytic $\left(\times 10^{6}\right)$ & 7.17 & 8.25 & 7.02 & 8.45 & 0.72 & NS & NS & NS \\
\hline \multicolumn{9}{|c|}{ Real-time PCR technique, copies/ml of rumen content } \\
\hline Total bacteria $\left(\times 10^{10}\right)$ & $5.51^{\mathrm{a}}$ & $7.41^{\mathrm{a}}$ & $2.27^{\mathrm{b}}$ & $5.09^{\mathrm{ab}}$ & 0.85 & $*$ & $*$ & NS \\
\hline Anaerobic fungi $\left(\times 10^{7}\right)$ & 0.93 & 2.57 & 1.46 & 1.93 & 0.70 & NS & NS & NS \\
\hline Methanogenes $\left(\times 10^{7}\right)$ & 1.32 & 1.45 & 1.03 & 0.98 & 4.95 & NS & NS & NS \\
\hline F. succinogens $\left(\times 10^{9}\right)$ & $2.15^{\mathrm{ab}}$ & $5.29^{\mathrm{a}}$ & $0.97^{\mathrm{b}}$ & $3.06^{\mathrm{ab}}$ & 0.95 & NS & $*$ & NS \\
\hline R. flavefaciens $\left(\times 10^{7}\right)$ & $0.50^{\mathrm{b}}$ & $2.63^{\mathrm{a}}$ & $0.31^{\mathrm{b}}$ & $0.59^{\mathrm{b}}$ & 0.34 & $*$ & $*$ & $*$ \\
\hline R. albus $\left(\times 10^{6}\right)$ & 3.01 & 2.56 & 3.16 & 4.48 & 1.35 & NS & NS & NS \\
\hline B. fibrisolvens $\left(\times 10^{9}\right)$ & $1.34^{\mathrm{a}}$ & $1.80^{\mathrm{ab}}$ & $4.62^{\mathrm{a}}$ & $2.63^{\mathrm{ab}}$ & 1.00 & $*$ & NS & NS \\
\hline M. elsdenii $\left(\times 10^{8}\right)$ & $1.78^{b}$ & $2.47^{\mathrm{ab}}$ & $5.08^{\mathrm{a}}$ & $3.60^{\mathrm{ab}}$ & 0.80 & $*$ & NS & NS \\
\hline
\end{tabular}

${ }^{1}$ Control = Non-supplementation with $\mathrm{CH}$ and $\mathrm{RBO} ; \mathrm{CH}=$ Concentrate with $\mathrm{CH} ; \mathrm{RBO}=\mathrm{Concentrate}$ with $4 \% \mathrm{RBO} ; \mathrm{CHRBO}=\mathrm{Concentrate}$ with $\mathrm{CH}$ plus 4\% RBO; Int. = Interaction. NS = non-significant difference $(\mathrm{p}>0.05)$.

$* \mathrm{p}<0.05{ }^{\mathrm{a}, \mathrm{b}}$ Values on the same row with different superscripts differ $(\mathrm{p}<0.05)$. SEM $=$ Standard error of the mean. 
Table 6. Effect of cassava hay and rice bran oil on milk yield and milk composition in lactating dairy cows

\begin{tabular}{|c|c|c|c|c|c|c|c|c|}
\hline \multirow{2}{*}{ Items } & \multirow{2}{*}{ Control $^{1}$} & \multirow{2}{*}{$\mathrm{CH}$} & \multirow{2}{*}{$\mathrm{RBO}$} & \multirow{2}{*}{ CHRBO } & \multirow{2}{*}{ SEM } & \multicolumn{3}{|c|}{ Contrast } \\
\hline & & & & & & $\mathrm{RBO}$ & $\mathrm{CH}$ & Int. \\
\hline Milk yield $(\mathrm{kg} / \mathrm{d})$ & 12.2 & 12.5 & 11.4 & 13.1 & 0.52 & NS & 0.08 & NS \\
\hline $3.5 \%$ FCM $(\mathrm{kg} / \mathrm{d})$ & 12.6 & 13.1 & 11.7 & 13.8 & 0.55 & NS & 0.06 & NS \\
\hline \multicolumn{9}{|c|}{ Milk composition (\%) } \\
\hline Fat & 3.7 & 3.8 & 3.6 & 3.7 & 0.16 & NS & NS & NS \\
\hline Protein & 3.2 & 3.3 & 3.4 & 3.5 & 0.16 & NS & NS & NS \\
\hline Lactose & 4.7 & 3.8 & 4.2 & 4.3 & 0.26 & NS & NS & NS \\
\hline Solids-not fat & 7.8 & 7.9 & 8.3 & 8.6 & 0.32 & NS & NS & NS \\
\hline Total solids & 12.3 & 12.5 & 11.9 & 12.6 & 0.48 & NS & NS & NS \\
\hline MUN (mg/dl) & 13.0 & 14.5 & 12.6 & 12.1 & 1.14 & NS & NS & NS \\
\hline
\end{tabular}

${ }^{1}$ Control = Non-supplementation with $\mathrm{CH}$ and $\mathrm{RBO} ; \mathrm{CH}=$ Concentrate with $\mathrm{CH} ; \mathrm{RBO}=$ Concentrate with $4 \% \mathrm{RBO}$; $\mathrm{CHRBO}=\mathrm{Concentrate}$ with $\mathrm{CH}$ plus $4 \% \mathrm{RBO}$; Int. $=$ Interaction. NS $=$ Non-significant difference $(\mathrm{p}>0.05)$.

$* p<0.05{ }^{a, b}$ Values on the same row with different superscripts differ $(p<0.05)$. SEM $=$ Standard error of the mean.

yield, fat and protein content. However, supplementing cassava hay for lactating dairy cows tended to increase milk yield, similar to the work of Wanapat (2001) and Kiyothong and Wanapat (2004). Furthermore, higher milk yield was found in cows fed concentrates containing cassava hay and $2.5 \%$ sunflower oil as compared with the control group (Chantaraparn and Wanapat, 2008). In addition, milk-urea nitrogen (MUN) was not significantly different among treatments.

\section{Milk fatty acid profile}

The fatty acid concentrations in milk fat are shown in Table 7. Fatty acid composition of milk was not affected by $\mathrm{CH}$ in lactating dairy cows diets. In contrast, concentration of fatty acids was influenced by RBO supplementation, which resulted in significantly lower $(\mathrm{p}<0.05)$ concentrations of both short chain ( $\mathrm{C} 4: 0$ to 12:0) and medium-chain FA (C14:0 to C16:1), and increased ( $\mathrm{p}<0.05)$ the proportion of long-chain $\mathrm{FA}(\geq \mathrm{C} 18: 0)$ in milk fat. Consistent with other studies, the C14-C16:1 was decreased in oil-feed groups (Vesely et al., 2009; Dai et al., 2011). Furthermore, long chain fatty acids increased with oil supplementation in this study, which was similar to the findings of Donovan et al. (2000) and Dai et al. (2011). The addition of lipid through seeds or as a free oil reduced the proportions of short-chain and medium-chain FA in milk. This apparent reduction in de novo synthesis of FA $(\leq \mathrm{C} 16: 0)$ in the mammary gland has been reported in diets that increase the supply of long chain FA (Grummer, 1991). RBO contains a large amount of long chain fatty acids $(75 \%$ of total fatty acids), especially a high level of $38.4 \% \%$ oleic acid (C18:1) and 34.4\% linoleic acid (C18:2) (Orthoefer, 2001). The addition of long-chain unsaturated oils has been shown to increase their secretion in milk fat and inhibit de novo synthesis, thus reducing short- and medium-chain FA in milk. Therefore, long chain fatty acids increased, while short and medium-chain fatty acids decreased in cows fed with $4 \%$ RBO.

The effects of $\mathrm{CH}$ and $\mathrm{RBO}$ on conjugated linoleic acid (CLA) in milk fat are shown in Table 8. Feeding cows with RBO significantly increased cis-9, trans-11 CLA and total CLA $(\mathrm{p}<0.05)$, as well as trans-10, while cis-12 CLA tended to be increased as a result of RBO supplementation $(p=0.08)$. This result was consistent with the finding of Dai et al. (2011) who reported that the inclusion of vegetable oils increased the concentration of cis-9, trans-11 CLA. Similarly, Dhiman et al. (2000) reported that feeding soybean oil at $4 \%$ or linseed oil at $4.4 \%$ of the diet increased the proportion of C18:2 cis-9, trans-11 CLA in milk fat by $x 4.2$. The CLA found in milk fat is derived from endogenous desaturation of C18:1 trans-11 and produced by the reaction involving the microorganism $B$. fibrisolvens in the rumen (Kim et al., 2008), and is absorbed and used directly (Griinari et al., 2000). In addition, several researchers have confirmed the active role of Butyrivibrio species in the partial or complete biohydrogenation of unsaturated C18 fatty acids (Jenkins et al., 2008), thus $B$. fibrisovents has a greater CLA-producing capacity than other bacteria (Kim et al., 2000). Moreover, Kim et al. (2002) recently identified a rumen bacterium, M. elsdenii, that produces significant quantities of trans-10, cis-12 CLA and also plays an important role in CLA production. In this study, populations of $B$. fibrisovents and $M$. elsdenii increased in RBO diets and thus increased C18:2 cis-9, trans-11 CLA and C18:2 trans-10, cis-12 CLA, respectively.

\section{CONCLUSIONS}

Supplementation with $\mathrm{CH}$ could improve DMI and milk yield in lactating dairy cows with no affect on rumen fermentation characteristics. RBO supplementation resulted in increased propionate, but decreased in acetate concentration and a decreased $\mathrm{C} 2: \mathrm{C} 3$ ratio and $\mathrm{CH}_{4}$. Furthermore, it decreased total bacteria and cellulolytic 
Table 7. Effect of cassava hay and rice bran oil on fatty acids composition in lactating dairy cows

\begin{tabular}{|c|c|c|c|c|c|c|c|c|}
\hline \multirow{2}{*}{$\begin{array}{l}\text { Items } \\
\qquad \text { (Fatty acid, \%) }\end{array}$} & \multirow{2}{*}{ Control $^{1}$} & \multirow{2}{*}{$\mathrm{CH}$} & \multirow{2}{*}{ RBO } & \multirow{2}{*}{ CHRBO } & \multirow{2}{*}{ SEM } & \multicolumn{3}{|c|}{ Contrast } \\
\hline & & & & & & RBO & $\mathrm{CH}$ & Int. \\
\hline$\overline{\mathrm{C} 4: 0}$ & 1.49 & 1.39 & 1.22 & 1.19 & 0.22 & NS & $\mathrm{NS}$ & NS \\
\hline C6:0 & 1.38 & 1.28 & 0.93 & 0.91 & 0.19 & 0.07 & NS & NS \\
\hline C8:0 & $1.10^{\mathrm{a}}$ & $1.04^{\mathrm{a}}$ & $0.69^{\mathrm{b}}$ & $0.64^{\mathrm{b}}$ & 0.13 & $*$ & NS & NS \\
\hline C10:0 & $2.94^{\mathrm{a}}$ & $2.99^{\mathrm{a}}$ & $1.69^{\mathrm{b}}$ & $1.56^{\mathrm{b}}$ & 0.29 & $*$ & NS & NS \\
\hline C11:0 & 0.33 & 0.33 & 0.98 & 0.17 & 0.41 & NS & NS & NS \\
\hline C12:0 & $4.72^{\mathrm{a}}$ & $4.78^{\mathrm{a}}$ & $2.11^{\mathrm{b}}$ & $1.45^{\mathrm{b}}$ & 0.72 & $*$ & NS & NS \\
\hline C13:0 & 0.19 & 0.16 & 3.11 & 0.10 & 1.52 & NS & NS & NS \\
\hline C14:0 & $16.73^{\mathrm{a}}$ & $14.95^{\mathrm{ab}}$ & $7.64^{\mathrm{c}}$ & $9.75^{\mathrm{bc}}$ & 1.55 & $*$ & NS & NS \\
\hline C14:1 & $1.28^{\mathrm{ab}}$ & $1.75^{\mathrm{a}}$ & $0.70^{c}$ & $0.96^{\mathrm{bc}}$ & 0.16 & $*$ & 0.05 & NS \\
\hline C15:0 & 0.22 & 0.05 & 0.02 & 0.26 & 0.14 & NS & NS & NS \\
\hline C15:1 & 0.01 & 0.01 & 0.76 & 0.01 & 0.75 & NS & NS & NS \\
\hline C16:0 & $37.09^{\mathrm{ab}}$ & $41.76^{\mathrm{a}}$ & $24.42^{\mathrm{b}}$ & $29.55^{\mathrm{ab}}$ & 3.69 & NS & NS & NS \\
\hline C16:1 & $2.72^{\mathrm{a}}$ & $3.26^{\mathrm{a}}$ & $1.37^{\mathrm{b}}$ & $1.41^{\mathrm{b}}$ & 0.35 & $*$ & NS & NS \\
\hline C17:0 & 0.03 & 0.06 & 0.07 & 0.02 & 0.03 & NS & NS & NS \\
\hline C17:1 & 0.32 & 0.48 & 5.33 & 0.25 & 2.55 & NS & NS & NS \\
\hline C18:0 & $9.64^{\mathrm{b}}$ & $9.94^{\mathrm{b}}$ & $20.66^{\mathrm{a}}$ & $13.22^{\mathrm{ab}}$ & 2.92 & $*$ & NS & NS \\
\hline C18:1n9c & 1.22 & 0.88 & 7.49 & 9.96 & 4.76 & NS & NS & NS \\
\hline $\mathrm{C} 18: 1 \mathrm{n} 9 \mathrm{t}$ & 9.53 & 5.84 & 13.57 & 20.29 & 5.00 & NS & NS & NS \\
\hline $\mathrm{C} 18: 2 \mathrm{n} 6 \mathrm{t}$ & $0.05^{\mathrm{b}}$ & $0.06^{\mathrm{b}}$ & $1.49^{\mathrm{a}}$ & $0.07^{\mathrm{b}}$ & 0.31 & $*$ & 0.06 & 0.06 \\
\hline $\mathrm{C} 18: 2 \mathrm{n} 6 \mathrm{c}$ & 0.02 & 0.06 & 0.03 & 0.28 & 0.03 & $*$ & NS & NS \\
\hline $18: 3 n 6$ & 0.10 & 0.03 & 0.30 & 0.04 & 0.09 & 0.08 & NS & NS \\
\hline C20:0 & 0.02 & 0.02 & 0.03 & 0.02 & 0.01 & NS & NS & NS \\
\hline C20:1 & 0.30 & 0.39 & 0.32 & 0.62 & 0.13 & NS & NS & NS \\
\hline C20:2 & 0.14 & 0.28 & 0.10 & 0.13 & 0.08 & NS & NS & NS \\
\hline C20:3n6 & 0.07 & 0.05 & 0.11 & 0.08 & 0.05 & NS & NS & NS \\
\hline $\mathrm{C} 22: 1 \mathrm{n} 9$ & 0.13 & 0.28 & 0.19 & 0.16 & 0.06 & NS & NS & NS \\
\hline Others & 6.15 & 5.42 & 5.33 & 4.51 & 0.37 & 0.06 & 0.08 & NS \\
\hline
\end{tabular}

${ }^{1}$ Control = Non-supplementation with $\mathrm{CH}$ and $\mathrm{RBO} ; \mathrm{CH}=$ Concentrate with $\mathrm{CH} ; \mathrm{RBO}=$ Concentrate with $4 \% \mathrm{RBO}$; $\mathrm{CHRBO}=\mathrm{Concentrate}$ with $\mathrm{CH}$ plus $4 \%$ RBO; Int. = Interaction. NS = Non-significant difference $(p>0.05)$.

$* p<0.05{ }^{a, b}$ Values on the same row with different superscripts differ $(p<0.05)$. SEM $=$ Standard error of the mean.

bacteria populations including $F$. succinogens and $R$. and composition in lactating dairy cows, although fatty acid flavefaciens whereas the populations of B. fibrisolvens and composition of milk was influenced by RBO M. elsdenii were increased in RBO diets. In addition, supplementation and was higher in C18:2 cis-9, trans-11 supplementing with RBO has no effect on milk production CLA and total CLA. These findings should be applied

Table 8. Effect of cassava hay and rice bran oil on conjugated linoleic acid (CLA) in milk fat

\begin{tabular}{|c|c|c|c|c|c|c|c|c|}
\hline \multirow{2}{*}{$\begin{array}{l}\text { CLA } \\
(\% \text { of fatty acid, } \%)\end{array}$} & \multirow{2}{*}{ Control $^{1}$} & \multirow{2}{*}{$\mathrm{CH}$} & \multirow{2}{*}{$\mathrm{RBO}$} & \multirow{2}{*}{ CHRBO } & \multirow{2}{*}{ SEM } & \multicolumn{3}{|c|}{ Contrast } \\
\hline & & & & & & $\mathrm{RBO}$ & $\mathrm{CH}$ & Int. \\
\hline \multicolumn{9}{|l|}{ Conjugated 18:2 } \\
\hline$c 9, t 11$ & $1.70^{\mathrm{b}}$ & $1.94^{\mathrm{ab}}$ & $2.05^{\mathrm{ab}}$ & $2.31^{\mathrm{a}}$ & 0.14 & $*$ & NS & NS \\
\hline$t 8, c 10$ & 0.05 & 0.07 & 0.06 & 0.08 & 0.04 & NS & NS & NS \\
\hline$c 10, t 12$ & 0.06 & 0.10 & 0.11 & 0.15 & 0.04 & NS & NS & NS \\
\hline$c 10, c 12$ & 0.11 & 0.15 & 0.09 & 0.08 & 0.05 & NS & NS & NS \\
\hline$c 11, c 13$ & 0.11 & 0.05 & 0.03 & 0.05 & 0.04 & NS & NS & NS \\
\hline$t 10, c 12$ & 0.10 & 0.11 & 0.14 & 0.21 & 0.04 & 0.08 & NS & NS \\
\hline$t 8, t 10+t 9, t 11+t 10, t 12$ & 0.06 & 0.01 & 0.08 & 0.07 & 0.05 & NS & NS & NS \\
\hline Total CLA & $2.19^{\mathrm{b}}$ & $2.43^{\mathrm{ab}}$ & $2.56^{\mathrm{ab}}$ & $2.97^{\mathrm{a}}$ & 0.20 & $*$ & NS & NS \\
\hline
\end{tabular}

${ }^{1}$ Control = Non-supplementation with $\mathrm{CH}$ and $\mathrm{RBO} ; \mathrm{CH}=$ Concentrate with $\mathrm{CH} ; \mathrm{RBO}=$ Concentrate with $4 \% \mathrm{RBO} ; \mathrm{CHRBO}=\mathrm{Concentrate}$ with $\mathrm{CH}$ plus $4 \%$ RBO; Int. = Interaction. NS = Non-significant difference $(\mathrm{p}>0.05)$.

$* \mathrm{p}<0.05 .{ }^{\mathrm{a}, \mathrm{b}}$ Values on the same row with different superscripts differ $(\mathrm{p}<0.05)$. SEM $=$ Standard error of the mean. 
further in practical dairy feeding in the tropics in order to increase production efficiency.

\section{ACKNOWLEDGEMENTS}

The authors would like to express their most sincere thank to the Office of the Higher Education Commission, Thailand for support under the program Strategic Scholarships for Frontier Research Network for the Joint Ph.D. program Thai Doctoral degree for this research. Tropical Feed Resources Research and Development Center (TROFREC), Faculty of Agriculture, Khon Kaen University, Khon Kaen, Thailand for their financial support of research and the use of research facilities. In addition, thanks are extended to the staff of the Department of Animal Science, Faculty of Natural Resources, Rajamangala University of Technology-Isan, Sakon Nakhon Campus for fatty acids profile analysis.

\section{REFERENCES}

AOAC. 1990. Official methods of analysis, 15th ed. Association of Official Analytical Chemists, Washington DC, USA.

Beauchemin, K. A., M. Kreuzer, F. O'Mara and T. A. McAllister. 2008. Nutritional management for enteric methane abatement: a review. Aust. J. Exp. Agric. 48:21-27.

Bell, J. A., J. M. Griinari and J. J. Kennelly. 2006. Effect of safflower oil, flaxseed oil, monensin, and vitamin $\mathrm{E}$ on concentration of conjugated linoleic acid in bovine milk fat. J. Dairy Sci. 89:733-748.

Bu, D. P., J. Q. Wang, T. R. Dhiman and S. J. Liu. 2007. Effectiveness of oils rich in linoleic and linolenic acids to enhance conjugated linoleic acid in milk from dairy cows. J. Dairy Sci. 90:998-1007.

Cant, J. P., A. H. Fredeen, T. MacIntyre, J. Gunn and N. Crowe. 1997. Effect of fish oil and monensin on milk fat composition in dairy cows. Can. J. Anim Sci. 77:125-131.

Chantaprasarn, N. and M. Wanapat. 2008. Effects of sunflower oil supplementation in cassava hay based-diets for lactating dairy cows. Asian-Aust. J. Anim. Sci. 21:42-50.

Clapperton, J. L. 1974. The effect of trichloroacetamide, chloroform and linseed oil given into the rumen of sheep on some of the end-products of rumen digestion. Br. J. Nutr. 32: 155-161.

Crocker, C. L. 1967. Rapid determination of urea nitrogen in serum or plasma without deproteinzation. Am. J. Med. Technol. 33:361-365.

Dai, X. J., C. Wang and Q. Zhu. 2011. Milk performance of dairy cows supplemented with rapeseed oil, peanut oil and sunflower seed oil. Czech J. Anim. Sci. 56:181-191.

Devendra, C. and D. Lewis. 1973. The interaction between dietary lipids and fibre in the sheep 1. A comparison of the methods used for crude fibre and acid-detergent fibre estimations. Anim. Prod. 17:275-280.

Dhiman, T. R., L. D. Satter, M. W. Pariza, M. P. Galli, K. Albright and M. X. Tolosa. 2000. Conjugated linoleic acid (CLA) content of milk from cows offered diets rich in linoleic and linolenic acid. J. Dairy Sci. 83:1016-1027.

Donovan, D. C., D. J. Schingoethe, R. J. Baer, J. Ryali, A. R. Hippen and S. T. Franklin. 2000. Influence of dietary fish oil on conjugated linoleic acid and other fatty acids in milk fat from lactating dairy cows. J. Dairy Sci. 83:2620-2628.

Doreau, M. and Y. Chilliard. 1997. Digestion and metabolism of dietary fat in farm animals. Br. J. Nutr. 78:S15-S35.

Goering, H. K. and P. J. Van Soest. 1970. Forage fiber analysis (apparatus, reagent, procedures and some application). Agric. Handbook No. 379, ARS, USDA, Washington, DC, USA.

Griinari, J. M., B. A. Corl, S. H. Lacy, P. Y. Chouinard, K. V. V. Nurmela and D. E. Bauman. 2000. Conjugated linoleic acid is synthesized endogenously in lactating dairy cows by $\Delta^{9}$ desaturase. J. Nutr. 130:2285-2291.

Grummer, R. R. 1991. Effect of feed on the composition of milk fat. J. Dairy Sci. 74:3244-3257.

Hess, B. W., G. E. Moss and D. C. Rule, 2008. A decade of developments in the area of fat supplementation research with beef cattle and sheep. J. Anim. Sci. 86(E-Suppl. 1):E188-E204.

Hess, B. W., M. B. Whitney and D. C. Rule. 2001. Site and extent of digestion by beef heifers fed medium-quality hay and supplemental corn or soybean oil. In: Proceedings of Western Section. Am. Soc. Anim. Sci. 52:469-472.

Hungate, R. E. 1969. A roll tube method for cultivation of strict anaerobes. In: Methods in Microbiology (Ed. J. R. Norris and D. W. Ribbons). Academic Press, New York, USA. p. 313.

Jenkins, T. C. and M. A. McGuire. 2006. Major advances in nutrition: Impact on milk composition. J. Dairy Sci. 89:13021310.

Kearl, L. C. 1982. Nutrient requirements of ruminants in developing countries. International Feedstuff Institute, Utah Agri. Exp. Sta, Utah State University, Logan, USA.

Kepler, C. R., K. P. Hirons, J. J. McNeill and S. B. Tove. 1966. Intermediates and products of the biohydrogenation of linoleic acid by Butyrivibrio fibrisolvens. J. Biol. Chem. 241:13501354.

Kim, E. J., S. A. Huws, M. R. F. Lee, J. D. Wood, S. M. Muetzel, R. J. Wallace and N. D. Scollan. 2008. Fish oil increases the duodenal flow of long chain polyunsaturated fatty acidsand trans-11 18:1 and decreases 18:0 in steers via changes in the rumen bacterial community. J. Nutr. 138:889-896.

Kim, Y. J., R. H. Liu, D. R. Bond and J. B. Russell. 2000. Effect of linoleic acid concentration on conjugated linoleic acid production by Butyrivibrio fibrisolvens A38. Appl. Environ. Microbiol. 66:5226-5230.

Kim, Y. J., R. H. Liu, J. L. Rychlik and J. B. Russell. 2002. The enrichment of a ruminal bacterium (Megasphaera elsdenii YJ4) that produces the trans-10, cis-12 isomer of conjugated linoleic acid. J. Appl. Microbiol. 92:976-982.

Kiyothong, K. and M. Wanapat. 2004. Supplementation of cassava hay and stylo 184 hay to replace concentrate for lactating dairy cows. Asian-Aust. J. Anim. Sci. 17:670-677.

Loor, J. J., A. Ferlay, A. Ollier, M. Doreau and Y. Chilliard. 2005. Relationship among trans and conjuaged fatty acids and bovine milk fat yield due to dietary concentrate and linseedoil. J. Dairy Sci. 88:726-740.

Lunsin, R., M. Wanapat, C. Yuangklang and P. Rowlinson. 2012. Effect of rice bran oil supplementation on rumen fermentation, milk yield and milk composition in lactating dairy cows. 
Livest. Sci. 145:167-173.

Maczulak, A. E., B. A. Dehority and D. L. Palmquist, 1981. Effects of long-chain fatty acids on growth of rumen bacteria. Appl. Environ. Microbiol. 42:856-862.

Mapato, C., M. Wanapat and A. Cherdthong. 2010. Effect of urea treatment of straw and dietary level of vegetable oil on lactating dairy cows. Trop. Anim. Health Prod. 42:1635-1642.

McDonald, P., R. A. Edwards, J. F. D. Greenhalgh and C. A. Morgan. 1996. Aninal Nutrition. Longman Singapore Publisher, Pte.

McGinn, S. M., K. A. Beauchemin, T. Coates and D. Colombatto. 2004. Methane emissions from beef cattle: effects of monensin, sunflower oil, enzymes, yeast, and fumaric acid. J. Anim. Sci. 82:3346-3356.

Metcalfe, L. D., A. A. Schmitz and J. R. Pelca. 1966. Rapid preparation of fatty acid esters from lipids for gas chromatographic analysis. Anal. Chem. 38:514-515.

Moss, A. R., J. P Jouany and J. Newbold, 2000. Methane production by ruminants: its contribution to global warming. Ann. Zootech. 49:231-253.

Nelson, G. J. 1975. Isolation and purification of lipids from animal tissues. In: Analysis of Lipids and Lipoproteins (Ed. E. G. Perkins). AOCS, Champaign, USA.

NRC. 2001. Nutrient requirements of dairy cattle. 7th Rev. Ed. National Research Council. National Academy of Science, Washington, DC, USA.

Onetti, S. G., R. D. Shaver, M. A. McGuire and R. R. Grummer. 2001. Effect of type and level of dietary fat on rumen fermentation and performance of dairy cows fed corn silagebased diets. J. Dairy Sci. 84:2751-2759.

Pantoja, J., J. L. Firkins, M. L. Eastridge and B. L. Hull, 1994. Effects of fat saturation and source of fiber on site of nutrient digestion and milk production by lactating dairy cows. J. Dairy Sci. 77:2341-2356

Roseler, D. K., J. D. Ferguson, C. J. Sniffen and J. Herrema. 1993. Dietary protein degradability effects on plasma and milk urea nitrogen and milk non-protein in Holstein cow. J. Dairy Sci. 76:525-534.

Samuel, M., S. Sagathewan, J. Thomas and G. Mathen. 1997. An HPLC method for estimation of volatile fatty acids of ruminal fluid. Indian J. Anim. Sci. 67:805-807.

SAS. 1998. SAS/STAT user's guide. Version 6.12. SAS Inst. Inc., Cary, NC, USA.

Satter, L. D. and L. L. Slyter. 1974. Effect of ammonia concentration on rumen microbial protein production in vitro. Br. J. Nutr. 32:199-208.

Shingfield, K. J., C. K. Reynolds, G. Hervas, J. M. Griinari, A. S. Grandison and D. E. Beever. 2006. Examination of the persistency of milk fatty acid composition responses to fish oil and sunflower oil in the diet of dairy cows. J. Dairy Sci. 89:714-732.
Steel, R. G. D. and J. H. Torrie. 1980. Principles and procedures of statistics: A Biometerial Approach (2nd ed.). McGraw-Hill, New York, USA.

Valadares, R. F. D., G. A. Broderick, S. C. Valadares Filho and M. K. Clayton. 1999. Effect of replacing alfalfa silage with high moisture corn on ruminal protein synthesis estimated from excretion of total purine derivatives. J. Dairy Sci. 82:26862696.

Van Keulen, J. and B. A. Young. 1977. Evaluation of acid insoluble ash as a neutral marker in ruminant digestibility studies. J. Anim. Sci. 44:282-287.

Vesely, A., L. Křižova, J. Třinacty, S. Hardova, M. Navratilova, I. Herzig and M. Fišera. 2009. Changes in fatty acid profile and iodine content in milk as influenced by the inclusion of extruded rapeseed cake in the diet of dairy cows. Czech J. Anim. Sci. 54:201-209.

Wanapat, M. 2001. Role of cassava hay as animal feed in the tropics. In: International Workshop Current Research and Development on Use of Cassava as Animal Feed (Ed. T. R. Preston, B. Ogle and M. Wanapat), Khon Kaen, Thailand. July 23-24, pp. 13-20.

Wanapat, M. 2002. Role of cassava hay as animal feeds in the tropics. In: Proceeding of Agricultural Conference, 27-29 January 2002, Chiangmai University, Chiangmai, Thailand, pp. 51-59.

Wanapat, M., A. Petlum and O. Pimpa, 2000a. Supplementation of cassava hay to replace concentrate use in lactating Holstein Friesian cross-breds. Asian-Aust. J. Anim. Sci. 13:600-604.

Wanapat, M. and O. Pimpa. 1999. Effect of ruminal $\mathrm{NH}_{3}-\mathrm{N}$ levels on ruminal fermentaion, purine derivatives, digestibility and rice straw intake in swamp buffaloes. Asian-Aust. J. Anim. Sci. 12:904-907.

Wanapat, M., T. Puramongkon and W. Siphuak. 2000b. Feeding of cassava hay for lactating dairy cows. Asian-Aust. J. Anim. Sci. 13:478-482.

Whitney, M. B., B. W. Hess, D. C. Rule and L. Brokaw. 1999. Effects of supplemental soybean oil on ruminal fermentation in beef heifers. In: Proceedings of Western Section. Am. Soc. Anim. Sci. 50:275-278.

Yang, S. L., D. P. Bu, J. Q. Wang, Z. Y. Hu, D. Li, H. Y. Wei, L. Y. Zhou and J. J. Loor. 2009. Soybean oil and linseed oil supplementation affect profiles of ruminal microorganisms in dairy cows. Animal 3:1562-1569.

Ye, J. A., C. Wang, H. F. Wang, H. W. Ye, B. X. Wang, H. Y. Liu, Y. M. Wang, Z. Q. Yang and J. X. Liu. 2009. Milk production and fatty acid profile of dairy cows supplemented with flaxseed oil, soybean oil, or extruded soybeans. Acta Agric. Scand. A. Anim. Sci. 59:121-129.

Yu, Z. and M. Morrison. 2004. Improved extraction of PCRquality community DNA from digesta and fecal samples. Biotechniques. 36:808-812. 